Author version: Nat. Hazards, vol.74(3); 2014; 1863-1879

\title{
A study on reflection pattern of swells from the shoreline of peninsular India
}

\author{
T.R.Anoop, V. Sanil Kumar, Johnson Glejin \\ Ocean Engineering, CSIR-National Institute of Oceanography (Council of Scientific \& Industrial \\ Research), Dona Paula, Goa 403 004, India URL: www.nio.org \\ Corresp.: V. Sanil Kumar (Tel: 00918322450 327; Fax: 00918322450 602; Email:sanil@nio.org)
}

\begin{abstract}
Information on reflected surface gravity waves from the shoreline is required for understanding the coastal hydrodynamics. We have quantified the reflected swells (frequency band 0.045 to $0.12 \mathrm{~Hz}$ ) from the west and east coast of India based on the spectral wave data derived from the directional wave rider buoys. Reflection coefficient, ratio of the reflected and incident spectral energy, was used to quantify the reflected waves. Influence of the seasons, cyclone, relative depth, land/sea breeze, tides and tidal current on the reflected waves were examined. For the locations off the west coast of India, seasons have large impact on the reflection coefficient and were relatively less during the monsoon season due to the increase in incident wave energy. Locations off the east coast of India show almost the same reflection coefficient throughout the year and have no significant seasonal variations. The reflection coefficient off Puducherry was higher than that for other locations due to the low incident wave energy. The reflection coefficient was low during the cyclone period, but the reflected energy during cyclone was higher than that during the normal condition due to the high incident wave energy. High energy reflected waves show large variation with tide due to the trapping and dissipation of reflected wave by bottom friction and this effect cause low reflection in deep water location than shallow water location. The reflection coefficient decreases with increase in relative depth off west coast of India.
\end{abstract}

Key Words: Ocean sciences; surface waves; reflected waves; relative depth; sea breeze; spectral energy density 


\section{Introduction}

The information on wave reflection from shoreline is required in many ocean engineering applications. In the laboratory studies, it is desirable to separate wave train into incident and reflected waves so that the model response can be in terms of parameters of the incident wave field. The reflected waves will also cause the generation of seismic noises and infra sounds (Hasselmann 1963; Szelwis 1982; Kedar et al. 2008; Stopa et al. 2010; Ardhuin et al. 2011) and to study these noises, information on waves reflected from the shoreline is necessary. The phase velocities depend on the spatial gradients of the wave action which can be over-predicted at locations where wave reflection is significant. Hence, the parameterization of shoreline reflection is required in the implementation of extended wave action equation that accounts for higher order depth and current gradients (Holthuijsen et al. 2003; Liau et al. 2011; Toledo et al. 2012). Miche (1951) studied the reflection of monochromatic waves normally incident on a laboratory beach and empirically determined a formula for estimating the ratio of reflected and incident wave energy based on deep water wave height $\left(\mathrm{H}_{\infty}\right)$, frequency $(\mathrm{f})$ and the beach slope $(\beta)$. Carrier and Greenspan (1958) found results similar to that of Miche (1951). Elgar et al. (1994) observed that the reflection coefficient $\left(\mathrm{R}^{2}\right)$ for swell-sea frequency band was qualitatively consistent with Miche hypothesis. Ardhuin et al. (2012) redefined the Miche hypothesis by replacing $\mathrm{H}_{\infty}$ with the significant wave height $\left(\mathrm{H}_{\mathrm{s}}\right)$ outside the surf zone and $\mathrm{f}$ with the mean frequency $\left(\mathrm{f}_{\mathrm{m} 0,1}\right)$ which is close to the "centroid frequency" used in the data analysis by Elgar et al. (1994). In the normal condition, less than 5 $\%$ of incident swell-sea band energy was reflected back and was up to $18 \%$ in lower energy band. The waves in the infra-gravity frequencies (Kinsman 1965) show higher reflection than the swell-sea band frequencies (Nelson et al. 1990; Elgar et al. 1994).

Investigation on wave reflection characteristics in the North Indian Ocean was not attempted due to the scarcity of measured directional wave data. The present study is a preliminary work on the reflection characteristics of surface gravity waves in the coastal region of peninsular India based on the measured wave data. The details of the locations studied are given in Table 1 and are also shown in Fig. 1. Large differences in geological and climatological features are present for the west and east coast of India and hence the locations off the west and east coast of India were selected for the study. Near shore region of East coast is very steep and narrow whereas it is broad and flat in the west coast. The effect of summer monsoon is higher in the west coast compared to that in the east coast. North Indian Ocean is frequented 
by cyclonic storms and the impact of cyclonic storm is higher in the Bay of Bengal than in the Arabian Sea (Singh et al. 2000). Among the locations studied four were in the eastern Arabian Sea and two were in the western Bay of Bengal. The waters off the Indian coast is exposed to seasonally reversing winds, with winds from the south-west (SW) during the summer monsoon period (June to September) and from the north-east (NE) during the winter monsoon period (October to January). The period between winter and summer monsoon is the pre-monsoon period or the fair weather (FW) period and the winter monsoon season is also called as post-monsoon season. The seasonal changes in winds produce similar changes in the surface waves (Kumar et al. 2012). The cyclonic storm causes the generation of low frequency waves with high energy (King and Shemdin 1978) and these waves will have impact on the reflection pattern. Hence, the reflection pattern of waves during cyclone was also investigated. The tides also influence the reflection pattern of waves (Nelson and Gonasalves 1990). Hence, we studied the seasonal changes in wave reflection off the Indian coastline. Apart from seasonal changes, we investigated the influence of cyclone, tides, tidal current, relative depth and land/sea breeze system on reflection pattern.

\section{Data and methodology}

The data used in the study were based on the measurements made using Directional waverider buoy (Barstow and Kollstad 1991) at water depth less than 15 m except one location off Honnavar (Table 1). The measurements were made in Coordinated Universal Time (UTC). The data recorded continuously at $1.28 \mathrm{~Hz}$ and the data for every 30 minutes were processed as one record. The collected time series was subjected to standard error checks for spikes, steepness and constant signals (Haver 1980). Wave spectrum was obtained through Fast Fourier transform (FFT). FFT of 8 series, each consisting of 256 measured vertical elevations of the buoy data, were added to obtain the spectrum. High frequency cut off was set at $0.58 \mathrm{~Hz}$ and the resolution was $0.005 \mathrm{~Hz}$. In the present study, we considered the spectral energy data only in the frequency corresponding to swell band $(0.045$ to $0.12 \mathrm{~Hz})$ because the data in the higher frequency range contains the wind wave generated by land/sea breeze (Neetu et al. 2006; Glejin et al. 2013a). By considering this frequency range, the edge waves also will not affect the results, because the edge waves generated by incident swells and wind waves have frequency range less than the limit considered in the present study (Guza and Davis 1974; Foda and Mei 1981; Buchan and Pritchard 1995). First the spectral energy density, $\mathrm{E}(\mathrm{f}, \theta)$ is calculated from the 3 time series motions of the buoy 
(vertical and 2 horizontal) using Extended Maximum Entropy Method (EMEM) (Hashimoto et. al. 1993). The coastal inclination of each location from the true north was obtained from the hydrographic chart produced by Naval Hydrographic Office, Government of India. Based on the coastal inclination, we separated the spectral energy density, $E(f, \theta)$ of shoreward propagating swells and the seaward propagating swells. For e.g., if the coastline is in the north-south direction with seaward side on west, then the waves with direction between 180 and $360^{\circ}$ is considered as incident waves and the waves between 0 and $180^{\circ}$ as reflected waves. The percentage of incident energy reflected back was calculated as reflection coefficient $\left(\mathrm{R}^{2}\right)$ using equation (1).

$$
\mathrm{R}^{2}=\frac{\int_{0.045}^{0.12} \int_{0}^{180} \mathrm{E}(\mathrm{f}, \theta) \mathrm{d} \theta \mathrm{df}}{\int_{0.045}^{0.12} \int_{180}^{360} \mathrm{E}(\mathrm{f}, \theta) \mathrm{d} \theta \mathrm{df}} \times 100
$$

Since the measurement locations were within a distance of less than five $\mathrm{km}$, except one location off Honnavar (18 km away from the shoreline), sufficient fetch was not available for generation of swell in the seaward direction (Table 1).

\section{Results and discussion}

\subsection{General wave characteristics}

Off the west coast of India, at Honnavar, the average value of $\mathrm{H}_{\mathrm{s}}$ was less than $1 \mathrm{~m}$ during the pre- and post-monsoon seasons and during the $\mathrm{SW}$ monsoon season, $\mathrm{H}_{\mathrm{s}}$ was in the range of 1 to $2 \mathrm{~m}$ (Sajiv et al. 2012). $H_{s}$ at Ratnagiri also varied with seasons, but have comparatively higher value than that at Honnavar (Glejin et al. 2012). At Ratnagiri, $H_{\mathrm{s}}$ varied from 3 to $4.5 \mathrm{~m}$ during the monsoon season and 0.9 to $1.7 \mathrm{~m}$ during the rest of the year (Glejin et al. 2013a). $\mathrm{H}_{\mathrm{s}}$ up to $6 \mathrm{~m}$ was reported off the west coast during the SW monsoon period (Kumar et al. 2006) and the $\mathrm{H}_{\mathrm{s}}$ was generally less than $1.5 \mathrm{~m}$ during the remaining period (Kumar and Anand 2004). At Puducherry, the location off the east coast of India, $\mathrm{H}_{\mathrm{s}}$ during $80 \%$ of time was between 0.75 and $1.5 \mathrm{~m}$ and the influence of monsoon was not significant at this location (Glejin et al. 2013b). At Visakhapatnam, even though high waves were observed during the FW and the NE monsoon period due to the cyclones, the average $\mathrm{H}_{\mathrm{s}}$ was high $(\approx 1.3 \mathrm{~m})$ during the SW monsoon period. 


\subsection{Influence of seasons}

The reflection pattern of swells from the west and east coast of peninsular India were different (Fig. 2). Along the west coast of India, less than five percentage of the incident spectral energy was reflected back during the SW monsoon season and a gradual increase was observed during the post (5 to $15 \%$ ) and pre-monsoon seasons (10 to $15 \%$ ). The variation in percentage of reflected waves in different season was due to the variation of incident wave spectral energy. According to Elgar et al. (1994), the reflection coefficient was inversely proportional to wave energy. The wave spectral energy off the west coast of India was high during the monsoon season (Kumar et al. 2006) and during monsoon season, the beaches of the west coast of India are very steep compared to other two seasons (Dora et al. 2012). Even though the steep beach slope is a supporting component to wave reflection (Elgar et al. 1994), its influence on wave reflection was less in present case. Also, the high frequency swells causes the reduction in percentage of wave reflection (Elgar et al. 1994). Off the west coast of India, the high frequency swells were higher during the monsoon season compared to pre- and post-monsoons (Kumar et al. 2012; Glejin et al. 2013a). Slightly higher reflection during the pre-monsoon season than that during the post-monsoon season was due to the presence of higher period of the incident swell during pre-monsoon season than the post-monsoon season. Reflection pattern of swells at all the locations off the west coast of India shows similar trend (Fig. 2).

Table 2 shows the monthly average percentage of the significant wave height of incident swells and reflected swells. The increase of the incident energy during the monsoon months were high whereas the corresponding increase in reflected energy was low. Among the three locations off the west coast, Karwar (70 km north of Honnavar) and Ratnagiri (200 km north of Honnavar) show higher reflection than Honnavar during the monsoon season. Higher reflection at Karwar and Ratnagiri were due to the presence of rocky island and cliffs in these locations since the cliffs enhanced the reflection. O'Reilly et al. (1999) observed increase in reflection coefficient up to $40 \%$ due to the presence of steep cliffs along the shoreline. The change in reflected spectral energy also influenced the wave height at these locations. But the same trend was not observed during the pre- and post-monsoon season due to the higher wave period during these seasons. Table 3 shows the incident and reflected angle from north. The incident and reflected angle is the same during the pre and post-monsoon seasons. Whereas, during the monsoon 
season, the incident angle is higher and corresponding increase in reflected angle occurs due to the monsoon wind.

Percentage of seaward propagating reflected swells off the east coast was not similar to that observed off the west coast of India. Unlike the west coast, the two locations studied off the east coast show different pattern in reflected wave since the distance between the locations studied was around $600 \mathrm{~km}$ and the wave characteristics off Puducherry differ from that at Visakhapatnam due to the shadow of the Sri Lankan landmass. The seasonal variations in $\mathrm{R}^{2}$ for east coast locations were not significant compared to the west coast locations. Among the locations studied, Puducherry shows higher reflection compared to other locations and at Puducherry, the influence of SW monsoon was not observed. Visakhapatnam show small variation in percentage of reflection during the SW monsoon season, but it was not significant as that of west coast locations. The percentage of reflected waves off Puducherry was in the range 15-20\% and that for Visakhapatnam was between 5 and $10 \%$. During February 2010, an abnormal decrease of incident wave energy was observed and this decrease in the incident energy caused an increase in percentage of reflection. The peak shows gradual decrease for Puducherry whereas rapid decrease was observed at Visakhapatnam. Off Visakhapatnam, the percentage of reflected waves was higher during post-monsoon season than pre-monsoon season (Table 2). The incident energy off Puducherry was lower than that off Visakhapatnam and hence higher $\mathrm{R}^{2}$ was found off Puducherry.

\subsection{Effect of relative depth}

The product of wave number (k) and water depth (d) is known as relative depth $(\mathrm{kd})$, where the wave number is calculated from the mean wave period of the swell using the linear dispersion equation. Monthly variation of $\mathrm{kd}$ is shown in Fig. 3. Off the west coast of India, kd shows maximum value during the monsoon months and its magnitude vary with depth. Maximum kd value is observed at Karwar and minimum is observed at Honnavar. For the locations in the east coast of the India, the variation of kd is less compared to the west coast locations because of less seasonal influence on wave climate in east coast compared to the west coast. In the case of Puducherry, the variation of kd with month is less compared to Visakhapatnam due to the sheltering of waves at Puducherry. 
By analyzing the monthly variation of $\mathrm{R}^{2}$ for the west coast locations, it is clear that relative depth and reflection coefficient is negatively correlated (Fig. 4). Based on the laboratory experiment Rytkonen (1988) found that increased wave length case increase in reflected energy and is the reason for decreasing reflection with increasing relative depth and vice versa. The kd values indicate that the wave length off the west coast of India is minimum during the monsoon season and is almost similar during the pre- and post-monsoon seasons. During the pre- and post-monsoon seasons, the swells propagating from the southern hemisphere reaches the eastern Arabian Sea and these swells are absent during the monsoon season (Glejin et al. 2012). These long period swells cause increased reflection during the preand post-monsoon seasons with low kd values compared to the monsoon season.

The variation in reflection coefficient at 2 water depths (9 and $30 \mathrm{~m}$ ) off Honnavar is studied for 23 days (24 Oct to 16 Nov 2012) during the post-monsoon season (Fig. 5). The reflection coefficient at 9-m and 30-m water depth are following same pattern, but the reflection coefficient is slightly higher at 9-m compared to $30-\mathrm{m}$. The buoy at $30-\mathrm{m}$ depth is $18 \mathrm{~km}$ away from shoreline and hence the reflected waves need to travel more distance to reach the buoy location. Hence, the reflected wave energy is less at 30-m water depth due to the dissipation of reflected wave by surface wind, bottom friction and other parameters.

\subsection{Impact of cyclone}

The cyclone causes generation of high waves, storm surges and edge waves. During the study, a very severe cyclonic storm 'THANE' crossed the study location off Puducherry (Kumar et al. 2013) and its impact was also observed off Visakhapatnam (Nair et al. 2013). Variation of reflection coefficient at these locations due to the influence of the cyclone was studied. According to Indian Meteorological Department (IMD) a depression was formed on 25 evening of December, 2011. This depression moved towards north-northwest direction and intensified into a cyclonic storm 'THANE' on 26 December. On 28 afternoons it changed into severe cyclonic storm and very severe cyclonic storm in the evening of 28 and crossed north Tamil Nadu and Puducherry coast between Cuddalore and Puducherry within 06:30 and 07:30 hrs IST of 30 December, 2011 with a wind speed of 120-140 kmph (Kumar et al. 2013). Track of the cyclone is given in Fig. 1. The high energy incident swells during cyclone time causes the generation of seaward propagating reflected waves. But compared to the amount of incident energy, the 
reflected wave energy was very low and hence low percentage of reflected waves was found during the cyclone period (Figs. 6 and 7). If we compare the seaward propagating energy during the cyclone with that during the normal condition it is higher. At both locations we can see that the magnitude of $\mathrm{R}^{2}$ decreases with increasing incident energy and there were two high and two low value of reflected energy per day due to the semi-diurnal nature of the tides along the Indian subcontinent (Figs. 6 and 7).

Off Puducherry, higher incident swell was observed at 12:00 UTC of 26 to 12:00 UTC of 27 December, 3 days before the arrival of 'THANE'. This high energy swell caused significant increase in reflected energy. During the 24 hours, the low and high tide has significant influence that leads to two high values and one low value. The high energy swell observed before the arrival of cyclone was due to wind pattern in the northern quadrant of the cyclone and its direction (actually in this time the storm was in the stage of deep depression and around $1000 \mathrm{~km}$ east of buoy location and moved in north direction). After this time, the incident energy decreased and corresponding decrease of reflected energy was observed due to

the change in direction of cyclone track (wind and waves on the different quadrant of the cyclone has different pattern).

Off Visakhapatnam, the reflected energy was lower than that observed off Puducherry during the time of cyclone 'THANE' since the measurement location was far away from the cyclone track. The duration of long period high energy waves before the arrival of cyclone was higher off Visakhapatnam than Puducherry since Visakhapatnam was on the right side of the cyclone track when it travels towards west. Hence, high energy incident swells generated by the cyclone, which travels ahead of it reaches Visakhapatnam until the cyclone reaches near Puducherry. This high energy long period swells causes corresponding increase in reflected energy.

\subsection{Effect of tides}

The tidal range at Karwar is $1.58 \mathrm{~m}$ at the time of spring tide and it is $0.72 \mathrm{~m}$ during the neap tide. The tidal range at Honnavar, which is around $70 \mathrm{~km}$ south of Karwar is $1.41 \mathrm{~m}$ during spring tide and $0.66 \mathrm{~m}$ during neap tide (Kumar et al. 2011). At Ratnagiri, the tidal range is 1.8 and $0.9 \mathrm{~m}$ respectively during the spring and neap tide and for Visakhapatnam, it is 1.43 and $0.54 \mathrm{~m}$ (Kumar et al. 2006). The effect of tide and tidal current on wave reflection pattern was studied at the southernmost location (Honnavar) in 
the west coast since measured wave, tide and current data was available for 31 days during 11 March to 11 April 2008. The variation of reflection coefficient along with tide and tidal current is shown in Fig. 8. The correlation of tide and tidal current with $\mathrm{R} 2$ is 0.18 and 0.69 respectively and both values have significance level greater than $95 \%$. The negative values of tidal current indicate the ebb velocities and positive sign for flood velocities.

The study shows that the tidal current has no significant influence on reflection pattern. In the study, waves in the swell band (lower frequency range) only are considered and the wave-current interaction is negligible in the swell band (Wolf et al. 1999). The good correlation between reflection pattern and tide is due to variation of sea level during various phases of the tide. The decreased (increased) water depth during low (high) tide time cause increased (decreased) trapping of seaward propagating reflected wave (Ardhuin et al. 2011) and addition to this increased (decreased) bottom friction causes enhanced (weaken) wave dissipation. These two factors play important role for decreasing (increasing) reflected wave energy during the time of low (high) tide.

Variations of $\mathrm{R}^{2}$ with low and high tide time for three locations in three seasons are shown in Table 4. From the table, we can see that for the locations in the east coast there was large variation in $\mathrm{R}^{2}$ at high and low tide than that for the west coast and this trend can be seen for all seasons including the cyclone period (Table 4). Along the coast line of India, mean sea level shows a different trend for east and west coast. Mean sea level decrease from north to south along the east coast and increase from north to south for west coast (Shankar et al. 2001). Visakhapatnam has higher sea level than that for the locations along the west coast. This difference in sea level and steepest bathymetry caused large difference in $\mathrm{R}^{2}$ during low and high tide. Between the two locations in the west coast, Karwar shows slightly higher difference in $\mathrm{R}^{2}$ at the time of low and high tide than Ratnagiri.

\subsection{Effect of sea breeze and land breeze system}

The relation between reflection coefficient and wind-sea height at two locations off Honnavar during the post-monsoon season (24 October to 16 November 2012) shows that the reflected wave height varies with wind-sea height (Fig. 9). According to Neetu et al. (2006) and Glejin et al. (2012) the wind-sea height of west coast of India during post-monsoon season is due to land/sea breeze system. Wind speed 
in this region is maximum at $12.30 \mathrm{UTC}$ and is in NW direction, land breeze system is observed in NE direction, but it is weak compared to the sea breeze.

The left panel of Fig. 9 shows variation of incident and reflected wave height and reflection coefficient with wind-sea height at 9-m depth (2.5 km away from coastline) and the right panel shows that for 30-m depth (18 km away from coastline). In both locations, reflection coefficient shows variation with windsea height (Figs. 9e and 9f) and this variation is due to the variation reflected wave height with wind-sea height (Figs. 9c and 9d). The reflected wave height during high land/sea breeze time shows a slight increasing trend and this small variation in reflected wave height produce changes in reflection percentage from 4 to 12 . Further study is needed to understand the reason for increased reflection during the time of high wind-sea height.

\section{Conclusion}

Reflection pattern of swells (frequency $=0.045$ to $0.12 \mathrm{~Hz}$ ) off the west and east coasts of the India were studied using directional wave data obtained from directional waverider buoys. The reflection coefficient off the west coast shows same trend at all locations. Along the west coast of India during the monsoon season, lower reflection coefficient was observed due to the increase in incident wave energy. Even though the beaches of west coast were steeper during the monsoon season, less influence was observed on reflection coefficient. Effect of seasons on reflection coefficient was not significant for locations off the east coast with slight variation off Visakhapatnam. Off Puducherry, large reflection coefficient was observed compared to other locations due to the low incident energy at this location. The reflection coefficient at all locations in the west coast of the India shows decreasing trend with increasing relative depth and such variation could not be observed for the locations in the east coast of India due to small variation in relative depth with season along the east coast of India. The percentage of reflected energy is decreasing towards offshore because of increased dissipation and trapping. The cyclone causes decrease in percentage of wave reflection due to the higher incident energy. During the cyclone period, the reflected energy was higher than that observed in the normal condition. The tides have higher influence on seaward propagation of reflected waves since the low tide causes increased

dissipation and trapping of seaward propagating waves by bottom friction. Wave-tidal current interaction was not observed for reflected wave due to the low frequency of reflected waves. The 
land/sea breeze system also influences the reflection coefficient and enhances the percentage of reflection.

\section{Acknowledgments}

The authors gratefully acknowledge the financial support given by the Earth System Science Organization, Ministry of Earth Sciences, Government of India to conduct this research. The Director of the CSIR-National Institute of Oceanography, Goa and the Director of the INCOIS, Hyderabad provided encouragement in carrying out the study. We thank Dr. T.M. Balakrishnan Nair, Head of the Ocean Science and Information Services Group of INCOIS, Hyderabad, Mr. Jai Singh, Technical Assistant at CSIR-NIO and Mr. Arun Nherakkol, Scientist, INCOIS for assistance during the data collection. This work forms a portion of the Ph.D. thesis by the first author. This work is NIO contribution No. Xxxx.

\section{References}

Ardhuin F, Roland A (2012) Coastal wave reflection, directional spread, and seismoacoustic noise sources. J Geophys Res 117 C00J20, doi:10.1029/2011JC007832.

Ardhuin F, Stutzmann E, Schimmel M, Mangeney A (2011) Ocean wave sources of seismic noise. J Geophys Res 116 C09004, doi:10.1029/2011JC006952.

Barstow SB, Kollstad T (1991) Field trials of the directional waverider. Proceedings of the First International Offshore and Polar Engineering Conference III. 55-63.

Buchan SJ, Pritchard WG (1995) Experimental observations of edge waves. J Fluid Mech 288:1-35.

Carrier GF, Greenspan HP (1958) Water waves of finite amplitude on a sloping beach. J Fluid Mech 4:97-109

Dora GU, Kumar VS, Glejin J, Sajiv PC, Vinayaraj P (2012) Short-term observation of beach dynamics using cross-shore profiles and foreshore sediment. Ocean Coast Manage 67:101-112

Elgar S, Herbers THC, Guza RT (1994) Reflection of ocean surface gravity waves from a natural beach. J Phys Oceanogr 24(7):1503-1511

Foda MA, Mei CC (1981) Nonlinear excitation of long trapped waves by a group of short swell. J Fluid Mech 111:319-345.

Glejin J, Kumar VS, Nair TMB (2013b) Monsoon and cyclone induced wave climate over the near shore waters off Puduchery, south western Bay of Bengal. Ocean Eng 72:277-286 http://dx.doi.org/10.1016/j.oceaneng.2013.07.013i. 
Glejin J, Kumar VS, Nair TMB, Singh J (2013a) Influence of winds on temporally varying short and long period gravity waves in the near shore regions of the eastern Arabian Sea. Ocean Sci 9:343-353

Glejin J, Kumar VS, Sajiv PC, Singh J, Pednekar P, Kumar KA, Dora GU, Gowthaman R (2012) Variations in swells along eastern Arabian Sea during the summer monsoon, Open J Mar Sci 2(2):43-50

Guza RT, Davis RE (1974) Excitation of edge waves by waves incident on a beach. J Geophys Res 79:1285-1291.

Hashimoto N, Nagai T, Asai T (1993) Modification of extended maximum entropy principle method for estimating directional spectrum in incident and reflected wave field. PHRI Report 32:25-47.

Hasselmann K (1963) A statistical analysis of the generation of microseisms. Rev Geophys 1(2):177210

Haver S (1980) Analysis of uncertainties related to the stochastic modeling of ocean waves. Division of Marine structures. The Norwegian Institute of Technology, Norway, Report No. UR-80-09, 187.

Holthuijsen LH, Herman A, Booij N (2003) Phase-decoupled refraction-diffraction for spectral wave models. Coastal Eng 49:291-305

Kedar S, Higgins ML, Graham FWN, Clayton R, Jones C (2008) The origin of deep ocean microseisms in the north Atlantic ocean, Proceedings in Royal Society, London A, 464:777-793, doi:10.1098/rspa.2007.0277.

King DB, and Shemdin OH (1979) Radar observations of hurricane wave directions. Proc. 16th Int. Conf. Coastal Eng Hamburg, Germany, ASCE, 209-226.

Kinsman B (1965) Wind waves, their generation and propagation on the ocean surface, Prentice Hall, Englewood Cliffs, NJ, pp.22-27.

Kumar VS (1999) Analysis of directional spreading of wave energy with special reference to Indian coast. Ph.D. thesis, Indian Institute of Technology, Bombay, India, $150 \mathrm{p}$

Kumar VS, Glejin J, Dubhashi KK, Nair TMB (2013) Waves off Puducherry, Bay of Bengal, during cyclone THANE. Nat Hazards 69: 509-522, DOI 10.1007/s11069-013-0713-z.

Kumar VS, Anand NM (2004) Variations in wave direction estimated using first and second order Fourier coefficients. Ocean Eng 31:2105-2119

Kumar VS, Dora GU, Philip S, Pednekar P, Jai Singh (2011) Variations in tidal constituents along the nearshore waters of Karnataka, west coast of India. J Coast Res 27 (5):824-829

Kumar VS, Johnson G, Dora GU, Philip SC, Singh J, Pednekar P (2012) Variations in nearshore waves along Karnataka, west coast of India. J Earth Syst Sci 121:393-403

Kumar VS, Pathak KC, Pednekar P, Raju NS, and Gowthaman R (2006) Coastal processes along the Indian coastline. Curr Sci India 91(4):530-536 
Liau J-M, Roland A, Hsu T-W., Ou S-H., Li Y-T (2011) Wave refraction-diffraction effect in the wind wave model WWM. Coastal Eng 58:429-443.

Miche A (1951) Le pouvoir réfléchissant des ouvrages maritimes exposés àl'action de la houle. Ann. Ponts Chaussees 121:285-319.

Nair BTM, Sirisha P, Sandhya KG, Srinivas K, Kumar VS, Sabique L, Nherakkol A, Prasad BK, Kumari CR, Jeyakumar, Kaviyazhahu K, Kumar MR, Harikumar R, Shenoi SSC, Nayak S (2013) Performance of the Ocean State Forecast system at Indian National Centre for Ocean Information Services. Curr Sci 105(2):175-181

Neetu S, Shetye S, Chandramohan P (2006) Impact of sea breeze on wind-seas off Goa, west coast of India. J Earth Sys Sci 15:2031-2038

Nelson RC, and J Gonsalves (1990) A field study of wave reflections from an exposed dissipative beach. Coastal Eng 14:457-477

O’Reilly WC, Guza RT, Seymour RJ (1999) Wave prediction in the Santa Barbara channel, Final technical report, Pac. Outer Cont. Shelf Reg., Miner. Manage. Serv., U. S. Dep. of Inter., Washington, D.C. [Available at http://www.coastalresearchcenter.ucsb.edu/cmi/files/ 2001-055.pdf.]

Rytktinen J (1988) Wind waves reflections -a case study. Rakenteiden Mekaniikka 1(1):55-65

Shankar D, and Shetye SR (2001) Why is mean sea level along the Indian coast higher in the Bay of Bengal than in the Arabian Sea?. J. Geophys Res Lett. 28:563-565

Singh OP, Khan TMA, Rahman S (2000) Changes in the frequency of tropical cyclones over the North Indian Ocean. Meteorology and Atmospheric Physics 75:11-20

Stopa JE, Cheung KF, Garcés MA, Fee D (2010) Source of microbaroms from tropical cyclone waves. Geophys Res Lett 38:L05602, doi:10.1029/2010GL046390.

Szelwis R (1982) Modeling of microseismic surface wave source. J Geophys Res 87:6906-6918

Toledo Y, Hsu T-W, Roland A (2012) Extended time-dependent mild-slope and wave-action equations for wave-bottom and wave-current interactions. In: Proceedings of Royal Society, London A, 468:184205

Wolf J, Prandle D (1999) Some observations of wave current interaction. Coast Eng 37:471-485 


\section{Figure Captions}

Figure 1. Study area and track of severe cyclonic storm 'THANE'. The depth contours are in meters

Figure 2. Monthly average percentage of reflected incident energy off west coast (top panel) and east coast of India (bottom panel) in different months

Figure 3. Monthly average of relative depth of west coast (top panel) and east coast (bottom panel) in different months

Figure 4. The plot of percentage of reflection with relative depth (a) for locations along the west coast and (b) for locations along the east coast of India

Figure 5. Hourly averaged (a) Incident wave height (b) reflected wave height and (c) reflection coefficient off Honnavar at 9-m and 30-m water depth

Figure 6. Wave reflection parameters off Puducherry coast during severe cyclonic storm THANE (a) percentage of reflection (b) $\mathrm{H}_{\mathrm{s}}$ of incident swell and (c) $\mathrm{H}_{\mathrm{s}}$ of reflected swell

Figure 7. Wave reflection parameters off Visakhapatnam coast during severe cyclonic storm THANE (a) percentage of reflection (b) $\mathrm{H}_{\mathrm{s}}$ of incident swell and (c) $\mathrm{H}_{\mathrm{s}}$ of reflected swell

Figure 8. Effect of tide and tidal current on wave reflection coefficient off Honnavar

Figure 9. Effect of land/sea breeze on $(a, b)$ incident swell $(c, d)$ reflected swell $(e, f) R^{2}$ off Honnavar at 9$\mathrm{m}$ and $30-\mathrm{m}$ water depth 
Table 1. Study locations along with distance from the shoreline and the water depth

\begin{tabular}{llllll}
\hline Location & Position & $\begin{array}{l}\text { Distance } \\
\text { from } \\
\text { shoreline } \\
(\mathrm{km})\end{array}$ & $\begin{array}{l}\text { Water } \\
\text { depth } \\
(\mathrm{m})\end{array}$ & $\begin{array}{l}\text { Coastline } \\
\text { inclination } \\
\text { with respect to } \\
\text { North (deg) }\end{array}$ & Data used (years) \\
\hline Honnavar (H) & $14.34^{\circ} \mathrm{N} ; 74.39^{\circ} \mathrm{E}$ & 2.5 & 9 & 343 & 2009 to 2011 \\
\hline Honnavar (H-30 m) & $14.35^{\circ} \mathrm{N} ; 74.24^{\circ} \mathrm{E}$ & 18 & 30 & 343 & $\begin{array}{l}24 \text { Oct to } 16 \mathrm{Nov} \\
2012\end{array}$ \\
\hline Karwar (K) & $14.82^{\circ} \mathrm{N} ; 74.05^{\circ} \mathrm{E}$ & 5.0 & 15 & 343 & 2011 \\
\hline Ratnagiri (R) & $16.98^{\circ} \mathrm{N} ; 73.25^{\circ} \mathrm{E}$ & 2.0 & 13 & 345 & 2010 to 2011 \\
\hline Puducherry (P) & $11.92^{\circ} \mathrm{N} ; 79.85^{\circ} \mathrm{E}$ & 2.0 & 14 & 15 & 2009 to 2011 \\
\hline Visakhapatnam (V) & $17.63^{\circ} \mathrm{N} ; 83.26^{\circ} \mathrm{E}$ & 2.0 & 15 & 40 & 2010 to 2011 \\
\hline
\end{tabular}


Table 2. Monthly average of incident $\left(\mathrm{H}_{\mathrm{i}}\right)$ and reflected $\left(\mathrm{H}_{\mathrm{r}}\right)$ significant wave height of swell $(\mathrm{m})$ for the locations studied

\begin{tabular}{|c|c|c|c|c|c|c|c|c|c|c|c|c|c|c|}
\hline & Year & & Jan & Feb & Mar & Apr & May & Jun & Jul & Aug & Sep & Oct & Nov & Dec \\
\hline & \multirow{2}{*}{2009} & $\mathrm{H}_{\mathrm{i}}$ & - & - & - & 0.70 & 0.73 & 1.09 & 1.85 & 0.93 & 0.89 & 0.78 & 0.70 & 0.66 \\
\hline & & $\overline{\mathrm{H}_{\mathrm{r}}}$ & - & - & - & 0.19 & 0.15 & 0.15 & 0.22 & 0.13 & 0.13 & 0.12 & 0.12 & 0.11 \\
\hline & \multirow{2}{*}{2010} & $\mathrm{H}_{\mathrm{i}}$ & 0.33 & 0.27 & 0.45 & 0.47 & 0.62 & 1.58 & 1.78 & 1.20 & 0.89 & 0.46 & 0.33 & 0.32 \\
\hline & & $\mathrm{H}_{\mathrm{r}}$ & 0.10 & 0.09 & 0.12 & 0.13 & 0.14 & 0.20 & 0.19 & 0.15 & 0.12 & 0.09 & 0.08 & 0.10 \\
\hline $\mathrm{H}$ & \multirow{2}{*}{2011} & $\mathrm{H}_{\mathrm{i}}$ & 0.29 & 0.29 & 0.37 & 0.45 & 0.61 & 1.75 & 1.59 & 1.23 & 1.24 & 0.62 & 0.41 & 0.33 \\
\hline & & $\mathrm{H}_{\mathrm{r}}$ & 0.10 & 0.09 & 0.12 & 0.13 & 0.13 & 0.17 & 0.17 & 0.14 & 0.15 & 0.14 & 0.12 & 0.11 \\
\hline \multirow[b]{2}{*}{ K } & \multirow[t]{2}{*}{2011} & $\overline{\mathrm{H}_{\mathrm{i}}}$ & 0.28 & 0.33 & 0.38 & 0.45 & 0.62 & 1.73 & 1.71 & 1.43 & 1.24 & 0.58 & 0.42 & 0.34 \\
\hline & & $\mathrm{H}_{\mathrm{r}}$ & 0.08 & 0.09 & 0.11 & 0.12 & 0.15 & 0.31 & 0.29 & 0.26 & 0.22 & 0.14 & 0.11 & 0.10 \\
\hline & \multirow[t]{2}{*}{2010} & $\overline{\mathrm{H}_{\mathrm{i}}}$ & - & - & 0.40 & 0.37 & 0.57 & 1.55 & 2.01 & 1.38 & 0.87 & 0.35 & 0.23 & 0.28 \\
\hline \multirow{3}{*}{$\mathrm{R}$} & & $\mathrm{H}_{\mathrm{r}}$ & - & - & 0.13 & 0.12 & 0.14 & 0.25 & 0.31 & 0.22 & 0.16 & 0.11 & 0.08 & 0.09 \\
\hline & \multirow{2}{*}{2011} & $\mathrm{H}_{\mathrm{i}}$ & 0.19 & 0.23 & 0.31 & 0.35 & 0.51 & 1.69 & 1.71 & 1.42 & 1.21 & 0.46 & 0.35 & 0.22 \\
\hline & & $\mathrm{H}_{\mathrm{r}}$ & 0.07 & 0.08 & 0.10 & 0.11 & 0.13 & 0.26 & 0.26 & 0.23 & 0.21 & 0.12 & 0.10 & 0.08 \\
\hline & 2009 & $\mathrm{H}_{\mathrm{i}}$ & 0.27 & 0.15 & 0.25 & 0.30 & 0.28 & 0.38 & 0.33 & 0.37 & 0.42 & 0.32 & 0.32 & 0.42 \\
\hline \multirow{5}{*}{$\mathrm{P}$} & \multirow{3}{*}{2010} & $\mathrm{H}_{\mathrm{r}}$ & 0.10 & 0.06 & 0.09 & 0.11 & 0.12 & 0.14 & 0.12 & 0.13 & 0.14 & 0.12 & 0.11 & 0.12 \\
\hline & & $\mathrm{H}_{\mathrm{i}}$ & 0.21 & 0.14 & 0.14 & 0.21 & 0.36 & 0.32 & 0.36 & 0.35 & 0.32 & 0.36 & 0.47 & 0.46 \\
\hline & & $\mathrm{H}_{\mathrm{r}}$ & 0.09 & 0.07 & 0.07 & 0.09 & 0.13 & 0.13 & 0.13 & 0.13 & 0.12 & 0.13 & 0.14 & 0.14 \\
\hline & \multirow{2}{*}{2011} & $\mathrm{H}_{\mathrm{i}}$ & 0.31 & 0.28 & 0.22 & 0.21 & 0.28 & 0.24 & 0.34 & 0.33 & 0.28 & 0.26 & 0.31 & 0.65 \\
\hline & & $\mathrm{H}_{\mathrm{r}}$ & 0.11 & 0.10 & 0.09 & 0.09 & 0.11 & 0.10 & 0.12 & 0.12 & 0.11 & 0.11 & 0.10 & 0.18 \\
\hline \multirow{4}{*}{ V } & \multirow[t]{2}{*}{2010} & $\mathrm{H}_{\mathrm{i}}$ & 0.41 & 0.33 & 0.50 & 0.68 & 0.94 & 0.95 & 0.97 & 1.01 & 1.08 & 0.78 & 0.55 & 0.48 \\
\hline & & $\mathrm{H}_{\mathrm{r}}$ & 0.11 & 0.10 & 0.10 & 0.12 & 0.15 & 0.16 & 0.16 & 0.17 & 0.18 & 0.17 & 0.13 & 0.12 \\
\hline & \multirow{2}{*}{2011} & $\mathrm{H}_{\mathrm{i}}$ & 0.42 & 0.54 & 0.46 & 0.64 & 0.78 & 0.63 & 0.64 & 0.83 & 0.73 & - & 0.57 & 0.78 \\
\hline & & $\mathrm{H}_{\mathrm{r}}$ & 0.11 & 0.10 & 0.10 & 0.12 & 0.15 & 0.16 & 0.16 & 0.17 & 0.18 & - & 0.13 & 0.12 \\
\hline
\end{tabular}


Table 3. Incident $\left(\boldsymbol{\theta}_{\mathbf{i}}\right)$ and reflected $\left(\boldsymbol{\theta}_{\mathrm{r}}\right)$ angle of swell with respect to north for the locations along the west coast of India

\begin{tabular}{|c|c|c|c|c|c|c|c|c|c|c|c|c|c|c|}
\hline Location & Year & & Jan & Feb & Mar & Apr & May & Jun & Jul & Aug & Sep & Oct & Nov & Dec \\
\hline \multirow{6}{*}{$\mathrm{H}$} & \multirow{2}{*}{2009} & $\boldsymbol{\theta}_{\mathrm{i}}$ & - & - & - & 233 & 234 & 247 & 264 & 251 & 242 & 238 & 237 & 235 \\
\hline & & $\boldsymbol{\theta}_{\mathrm{r}}$ & - & - & - & 102 & 110 & 123 & 130 & 123 & 117 & 114 & 110 & 109 \\
\hline & \multirow{2}{*}{2010} & $\theta_{i}$ & 233 & 234 & 232 & 229 & 232 & 255 & 255 & 250 & 245 & 233 & 230 & 232 \\
\hline & & $\boldsymbol{\theta}_{\mathrm{r}}$ & 101 & 105 & 106 & 107 & 117 & 129 & 127 & 125 & 123 & 117 & 105 & 99 \\
\hline & \multirow{2}{*}{2011} & $\boldsymbol{\theta}_{\mathrm{i}}$ & 231 & 233 & 231 & 229 & 232 & 258 & 255 & 250 & 245 & 231 & 231 & 230 \\
\hline & & $\boldsymbol{\theta}_{\mathrm{r}}$ & 97 & 103 & 105 & 108 & 117 & 133 & 130 & 126 & 120 & 99 & 97 & 100 \\
\hline \multirow{2}{*}{ K } & \multirow{2}{*}{2011} & $\boldsymbol{\theta}_{\mathrm{i}}$ & 225 & 225 & 224 & 222 & 226 & 253 & 252 & 248 & 239 & 224 & 226 & 223 \\
\hline & & $\boldsymbol{\theta}_{\mathrm{r}}$ & 112 & 116 & 116 & 119 & 122 & 124 & 124 & 125 & 123 & 116 & 110 & 113 \\
\hline \multirow{4}{*}{$\mathrm{R}$} & \multirow[b]{2}{*}{2010} & $\theta_{\mathrm{i}}$ & - & - & 231 & 233 & 237 & 256 & 258 & 254 & 249 & 238 & 235 & 234 \\
\hline & & $\boldsymbol{\theta}_{\mathrm{r}}$ & - & - & 104 & 108 & 116 & 123 & 123 & 124 & 116 & 106 & 95 & 98 \\
\hline & \multirow{2}{*}{2011} & $\theta_{i}$ & 236 & 238 & 236 & 234 & 240 & 259 & 257 & 257 & 248 & 234 & 236 & 236 \\
\hline & & $\boldsymbol{\theta}_{\mathrm{r}}$ & 107 & 109 & 106 & 109 & 117 & 129 & 125 & 125 & 118 & 101 & 98 & 108 \\
\hline
\end{tabular}

Table 4. Reflection coefficient $\left(\mathrm{R}^{2}\right)$ at the time of high tide and low tide. Values in parentheses shows that during the time of cyclone "THANE"

\begin{tabular}{lllllll}
\hline Location & FW & \multicolumn{3}{l}{ SW } & NE & Low tide \\
\cline { 2 - 7 } & High tide & Low tide & High tide & Low tide & High tide & L \\
\hline Karwar & 8.3 & 7.6 & 3.2 & 2.8 & 8.4 & 7.3 \\
\hline Ratnagiri & 12.2 & 11.7 & 2.7 & 2.6 & 12 & 11.4 \\
\hline Visakhapatnam & 8 & 3.2 & 9.9 & 3.8 & $10.4(7.7)$ & $5.3(3.3)$ \\
\hline
\end{tabular}




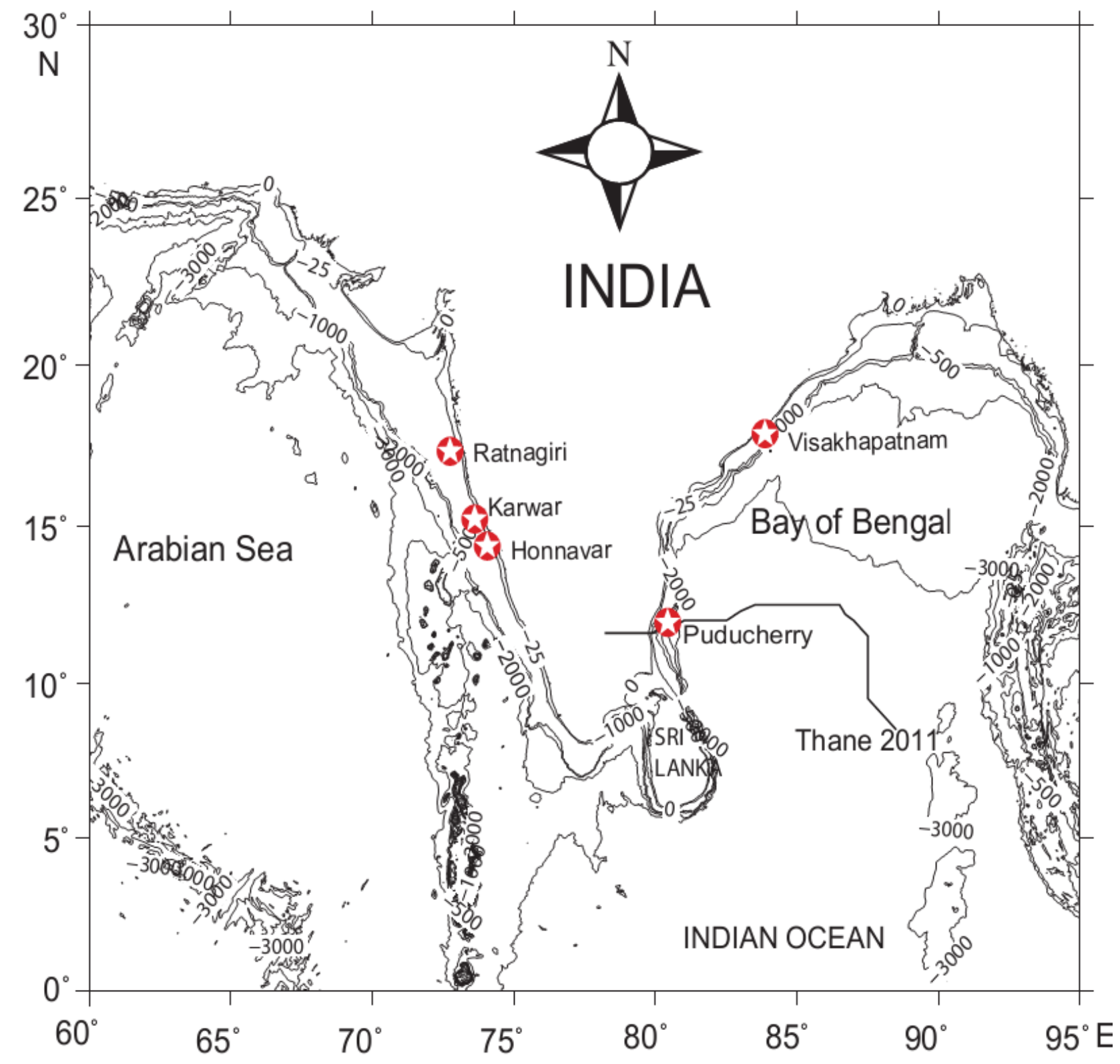

Figure 1. Study area and track of severe cyclonic storm 'THANE'. The depth contours are in meters 


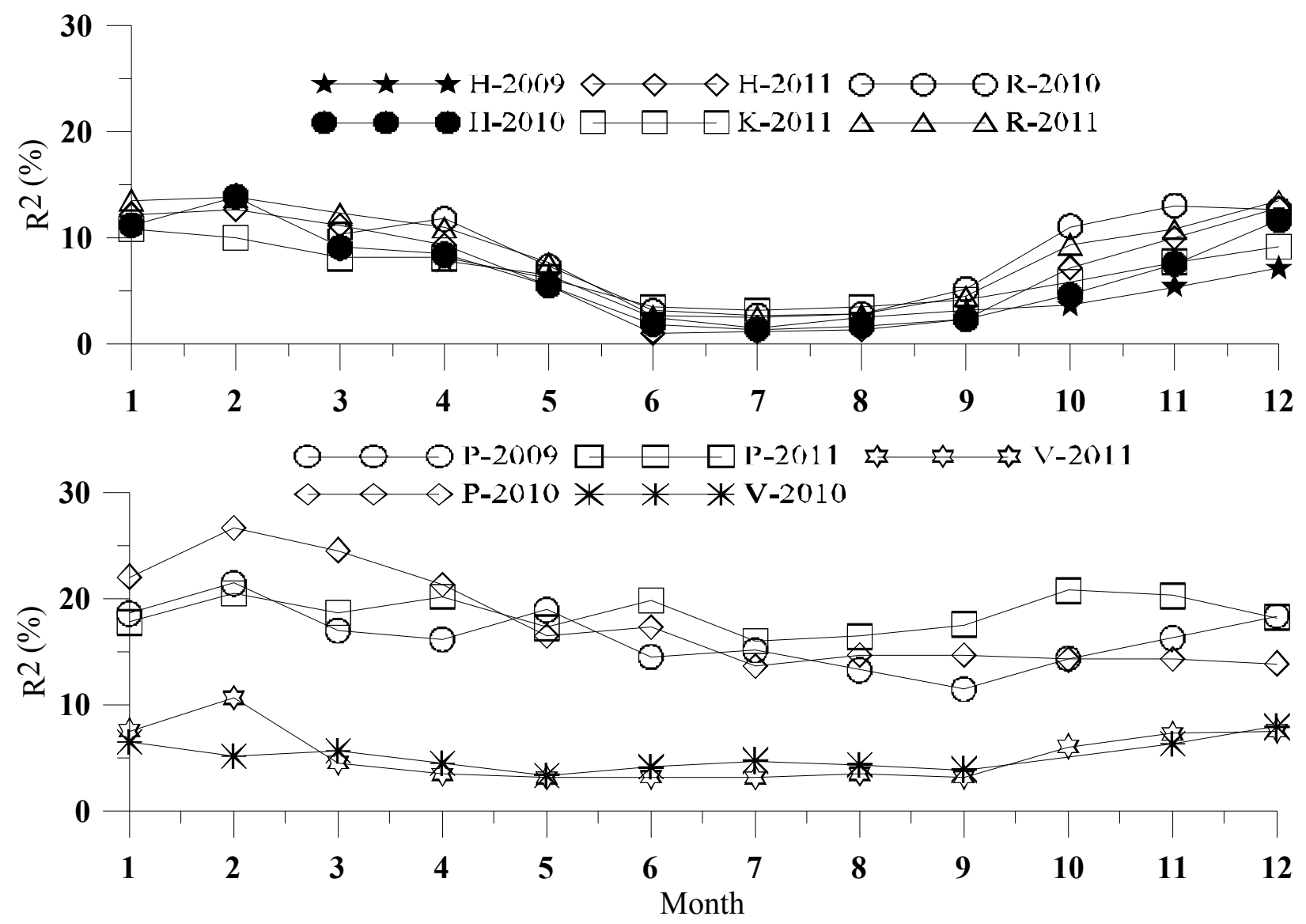

Figure 2. Monthly average percentage of reflected incident energy off west coast (top panel) and east coast of India (bottom panel) in different months 

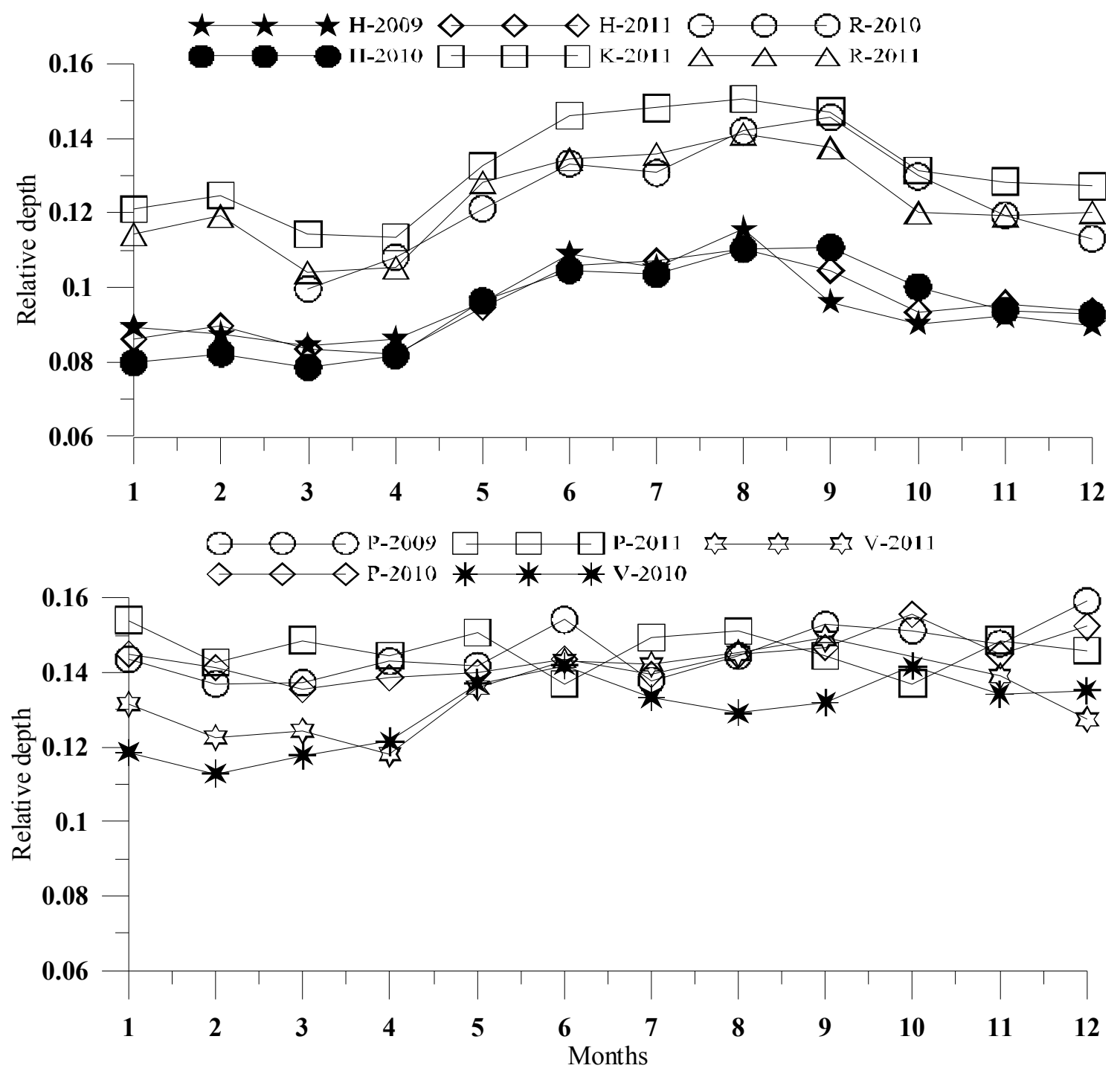

Figure 3. Monthly average of relative depth for locations along west coast (top panel) and that along east coast (bottom panel) of India in different months 

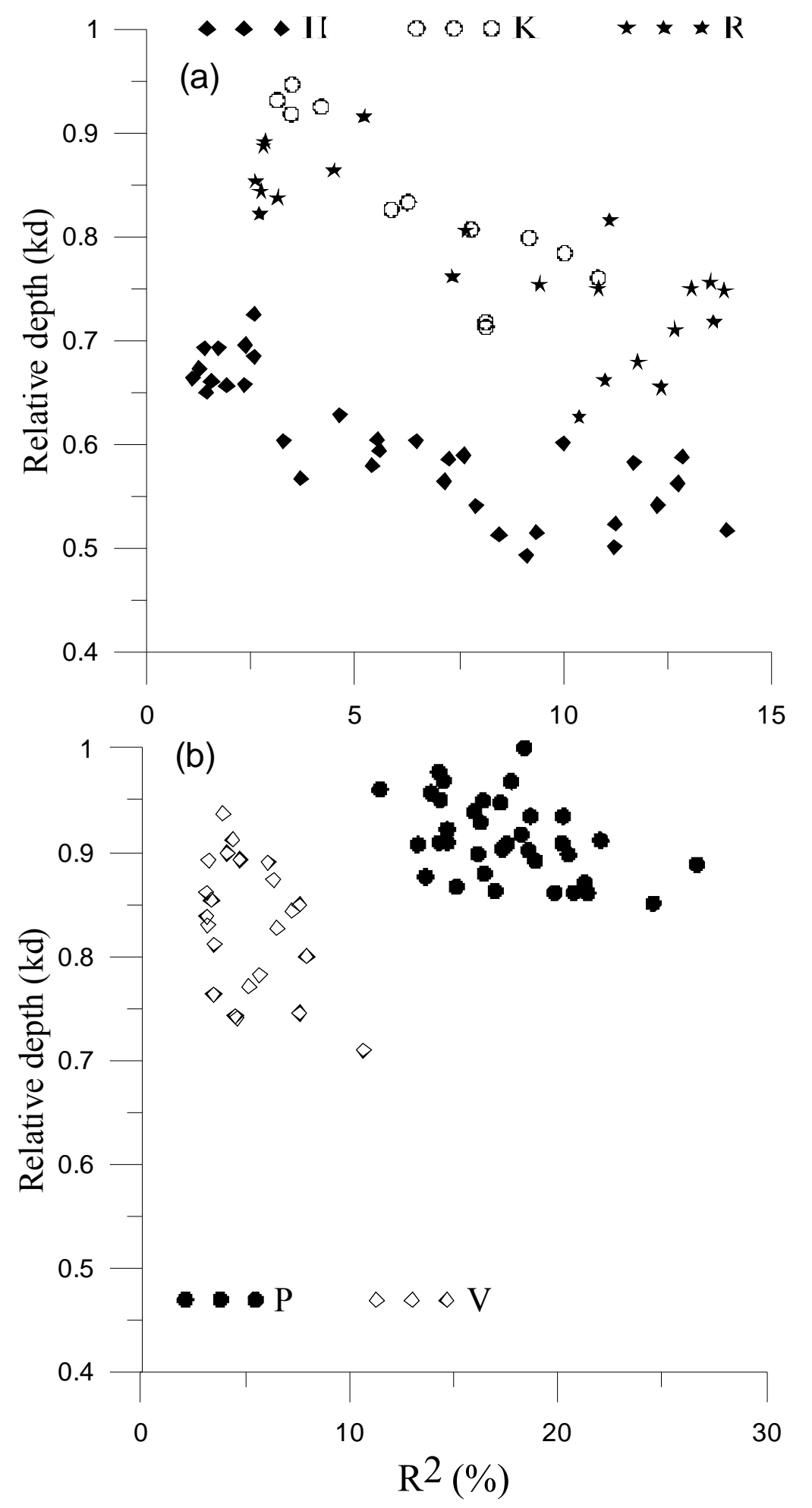

Figure 4. The plot of percentage of reflection with relative depth (a) for locations along the west coast and (b) for locations along the east coast of India 

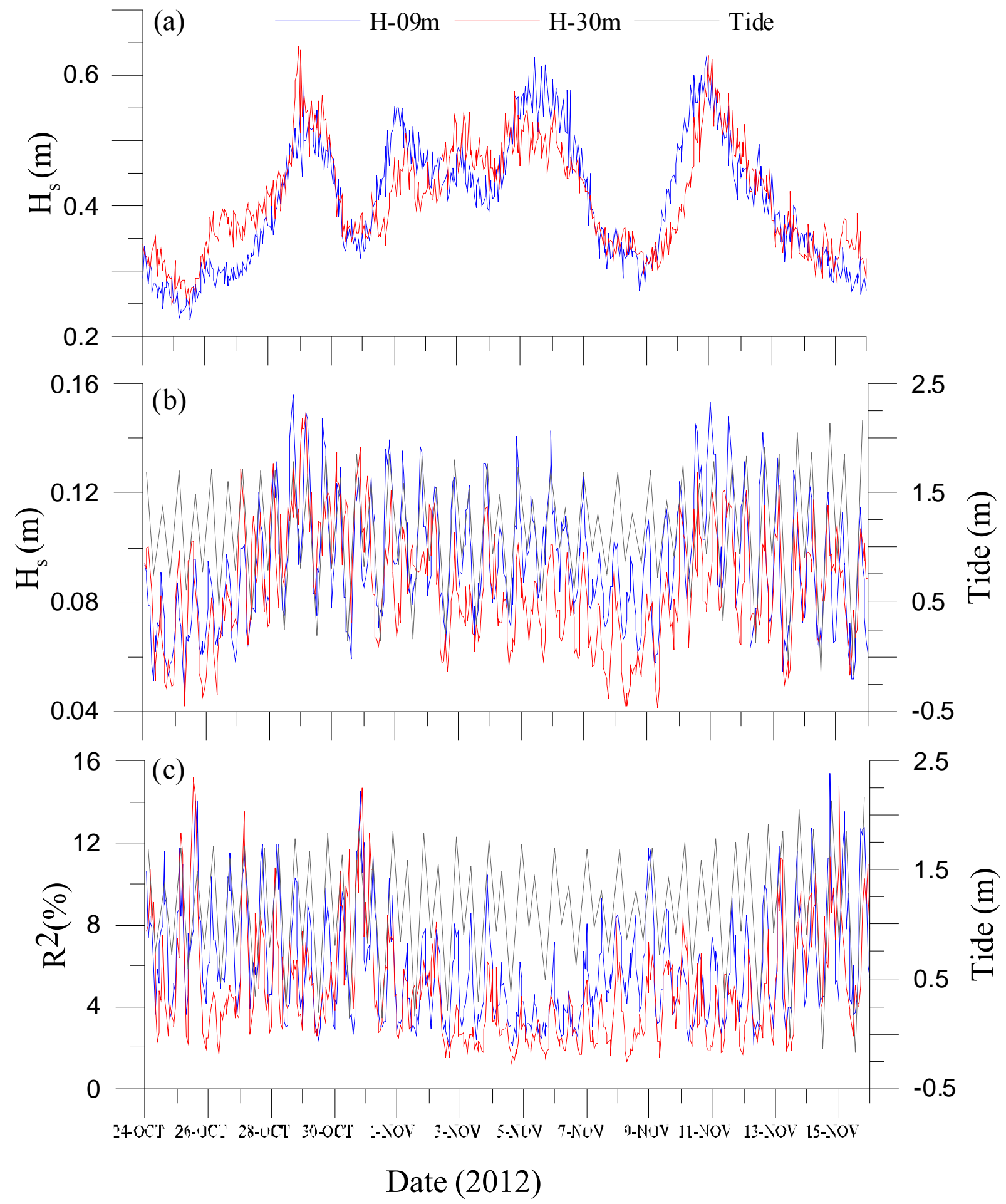

Figure 5. Hourly averaged (a) Incident wave height (b) reflected wave height and (c) reflection coefficient off Honnavar at $9 \mathrm{~m}$ and $30 \mathrm{~m}$ water depth 


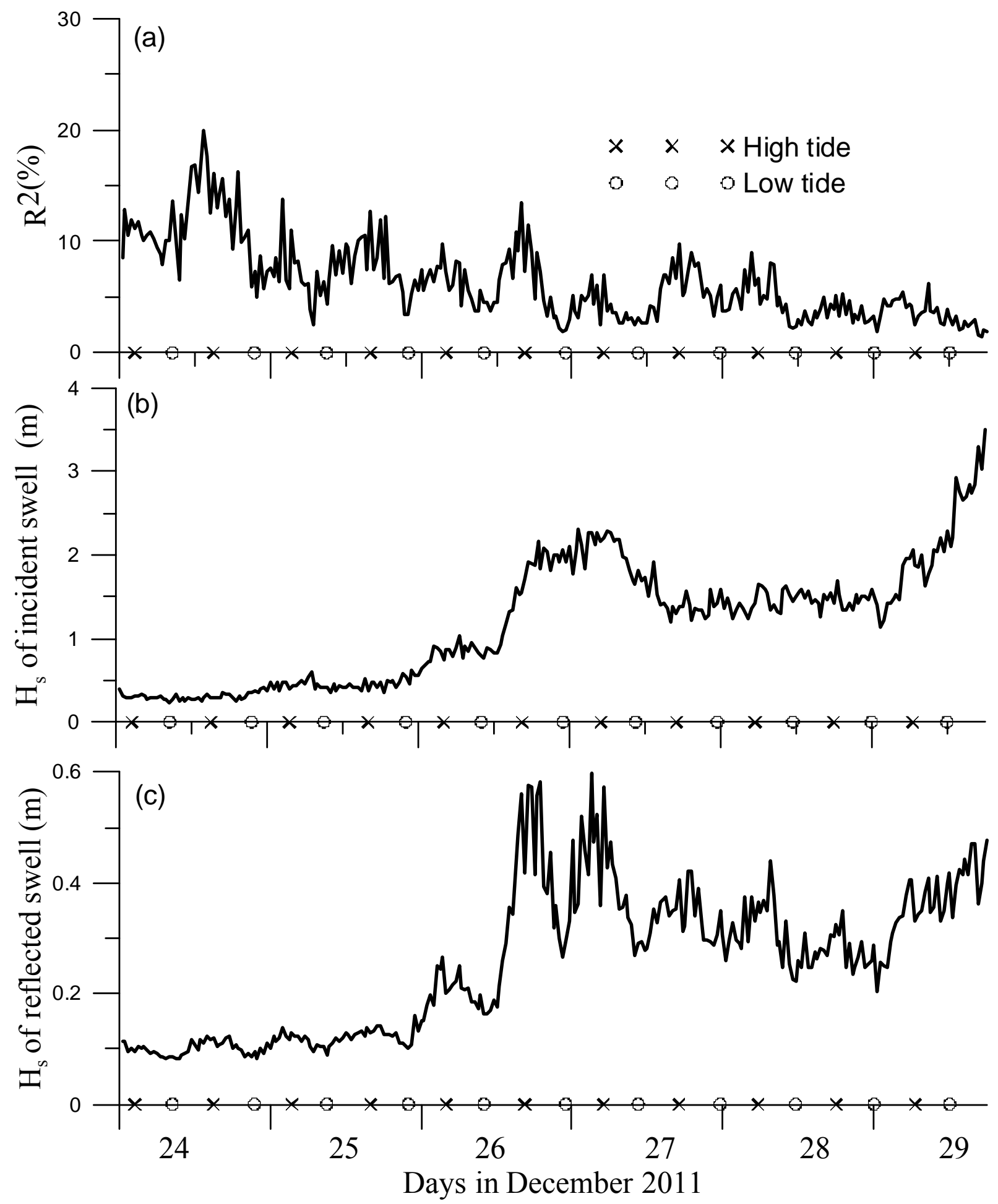

Figure 6. Wave reflection parameters off Puducherry coast during severe cyclonic storm THANE (a) percentage of reflection (b) $\mathrm{H}_{\mathrm{s}}$ of incident swell and (c) $\mathrm{H}_{\mathrm{s}}$ of reflected swell 

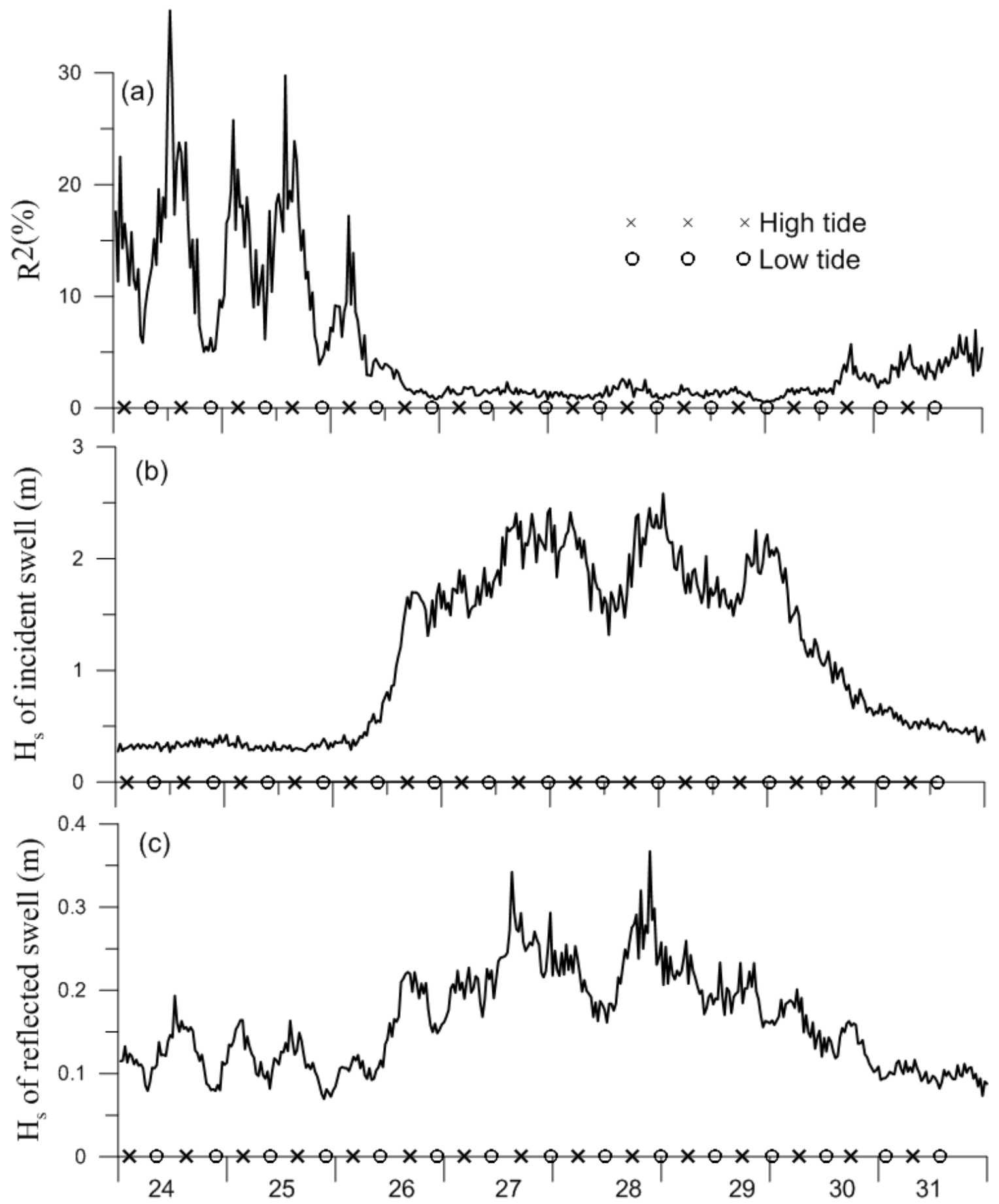

Days in December 2011

Figure 7. Wave reflection parameters off Visakhapatnam coast during severe cyclonic storm THANE (a) percentage of reflection (b) $\mathrm{H}_{\mathrm{s}}$ of incident swell and (c) $\mathrm{H}_{\mathrm{s}}$ of reflected swell 


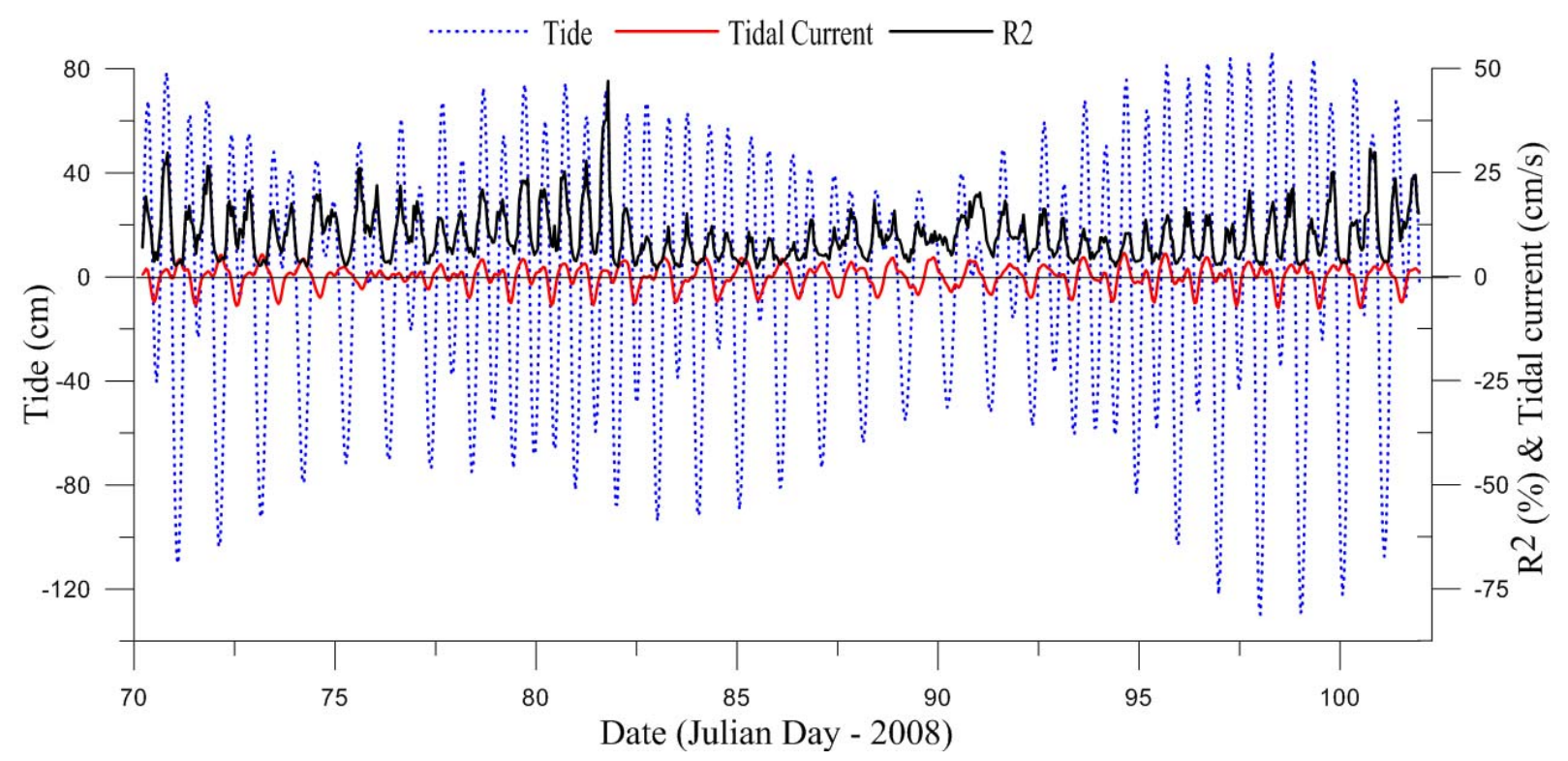

Figure 8. Effect of tide and tidal current on wave reflection coefficient off Honnavar 


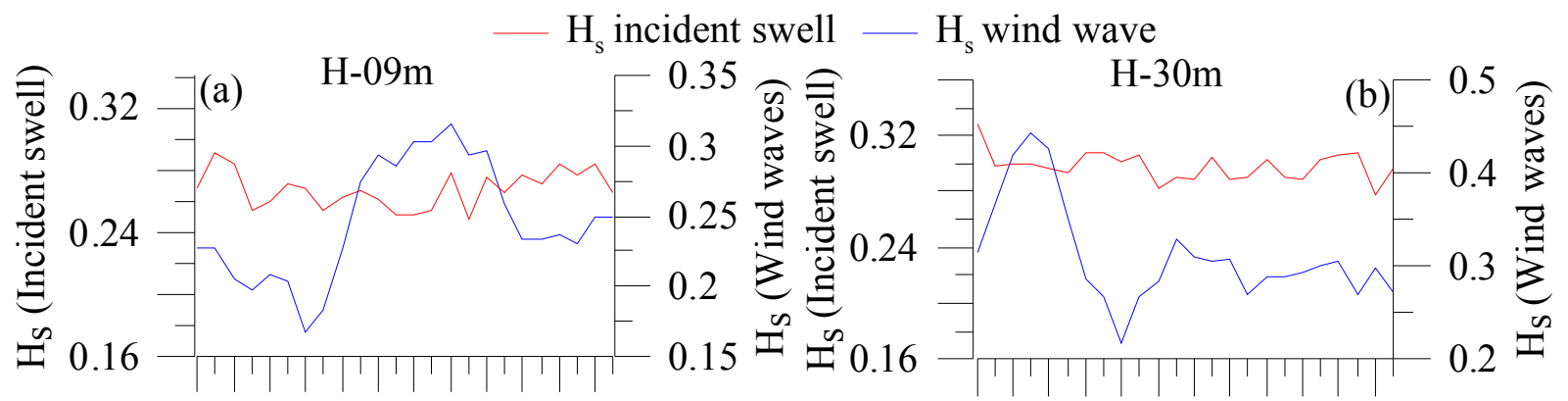

$-\mathrm{H}_{\mathrm{s}}$ reflected swell $-\mathrm{H}_{\mathrm{S}}$ wind waves
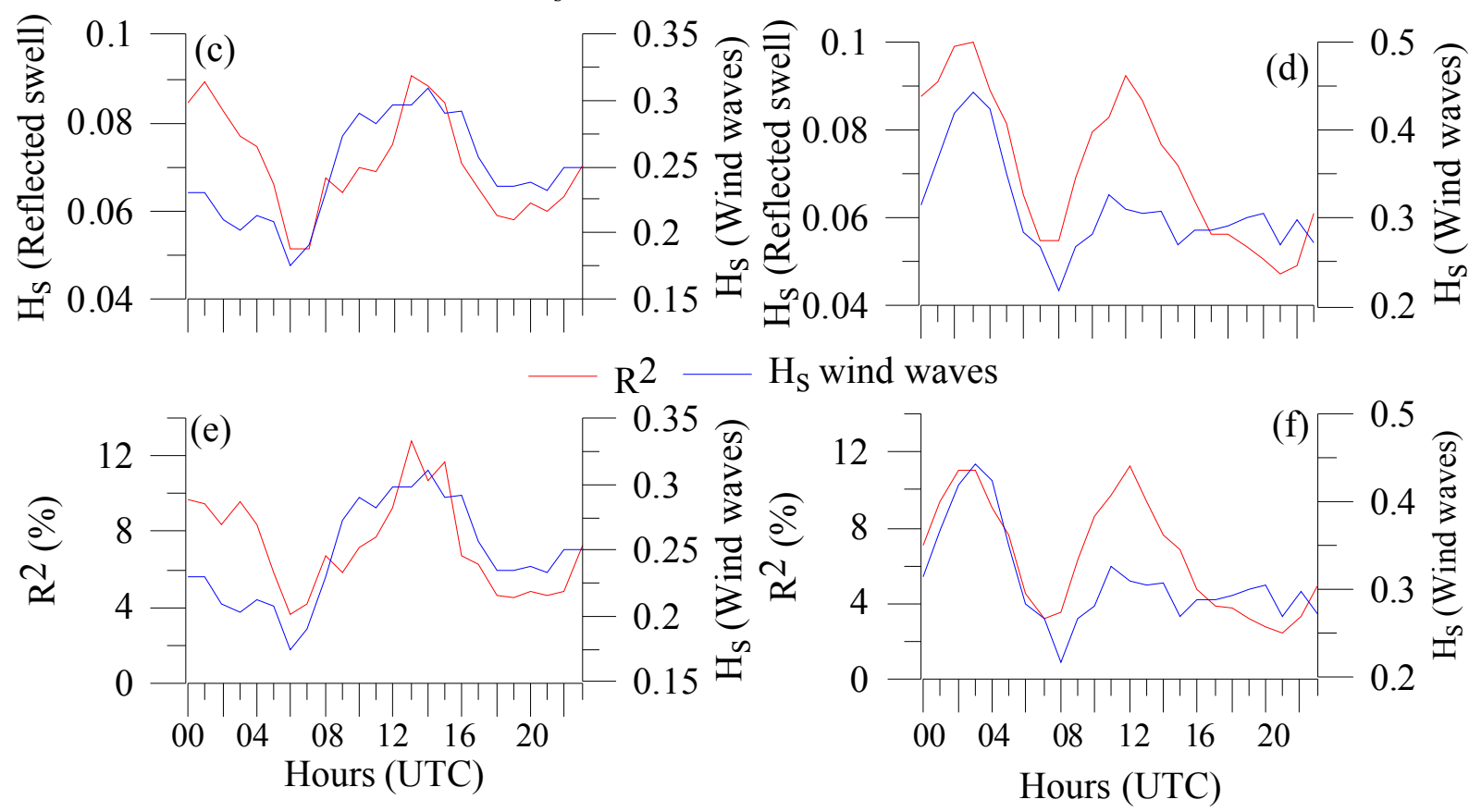

Figure 9. Effect of land/sea breeze on $(a, b)$ incident swell $(c, d)$ reflected swell $(e, f) R^{2}$ off Honnavar at 9$\mathrm{m}$ and 30-m water depth 